\title{
The Study of Public Management: Conceptualizing a Design-Oriented Social Science
}

\author{
Michael Barzelay \\ London School of Economics and Political Science
}

Talking about the field of public management is a convenient way to idealize research, teaching, and learning about aspects of public policy and administration. The view that public management is concerned with the development and operation of public programs and government organizations falls within the idealization. So, too, does the field's interdisciplinary constitution. However, what works in staging public management within a patchwork of strategic action fields - universities, the social science academy, and public administration professionals - does not provide a basis for academics to address deeper questions about its character. The need to address such questions has been forcefully stated by the field's leading thinkers, from time to time. This paper idealizes public management as a design-oriented social science, similar in concept to what Herbert Simon called a proper "science of the artificial." The paper shows that to idealize public management in such a way requires much clarification (and extension) of Simon's own ideas as he presented them. The resulting idealization of public management as a field of study provides a basis for a rich dialogue about the pursuit of academic excellence in the study of public policy and administration.

Keywords: public administration, public policy, social sciences, research

\footnotetext{
${ }^{1}$ Paper prepared for the International Workshop on Designing Governance for Policy Effectiveness, Lee Kuan Yu School of Public Policy, National University of Singapore, February 25-26, 2016. The writing of this paper has benefited very substantially from a period in the USA as a visiting professor at the Hubert $\mathrm{H}$. Humphrey School of Public Affairs, University of Minnesota, and from another period in France as a visiting researcher at the Centre de Recherche en Gestion (CRG), a research center at École Polytechnique, during a sabbatical leave from the LSE.
}

[Artigo recebido em 1ㅇ de fevereiro de 2018. Aprovado em 5 de março de 2018.] 


\section{O estudo da gestão pública: conceituando uma ciência social orientada ao design}

Falar sobre o campo da gestão pública é uma forma conveniente de idealizar pesquisa, ensino e aprendizagem sobre aspectos de políticas públicas e administração. A visão de que a gestão pública está preocupada com o desenvolvimento e a operação de programas públicos e organizações governamentais está dentro da idealização. O mesmo acontece com a constituição interdisciplinar do campo. No entanto, o que funciona na encenação da gestão pública dentro de uma colcha de retalhos de campos de ação estratégica - universidades, a academia de ciências sociais e profissionais da administração pública - não fornece uma base para os acadêmicos abordarem questões mais profundas sobre seu caráter. A necessidade de abordar tais questões foi enfaticamente declarada pelos principais pensadores do campo, de tempos em tempos. Este artigo idealiza a gestão pública como uma ciência social orientada para o design, similar em conceito ao que Herbert Simon chamou de "ciência do artificial". $\mathrm{O}$ artigo mostra que idealizar a gestão pública de tal forma requer muito esclarecimento (e extensão) das próprias idéias de Simon como ele as apresentou. A idealização resultante da gestão pública como campo de estudo fornece uma base para um rico diálogo sobre a busca da excelência acadêmica no estudo de políticas públicas e administração.

Palavras-chave: administração pública, políticas públicas, ciências sociais, pesquisa

\section{El estudio de la gestión pública: conceptualización de una ciencia social orientada al diseño}

Hablar sobre el campo de la gestión pública es una forma conveniente de idealizar la investigación, la enseñanza y el aprendizaje sobre aspectos de las políticas públicas y la administración. La visión de que la gestión pública está interesada en el desarrollo y operación de programas públicos y organizaciones gubernamentales cae dentro de la idealización. Lo mismo ocurre con la constitución interdisciplinaria del campo. Sin embargo, lo que funciona en la puesta en escena de la gestión pública dentro de un mosaico de campos de acción estratégica -universidades, la academia de ciencias sociales y profesionales de la administración pública- no proporciona una base para que los académicos aborden cuestiones más profundas sobre su carácter. La necesidad de abordar tales preguntas ha sido formulada enérgicamente por los principales pensadores del campo, de vez en cuando. Este documento idealiza la gestión pública como una ciencia social orientada al diseño, similar en concepto a lo que Herbert Simon llamó una "ciencia de lo artificial" propiamente dicha. El documento muestra que idealizar la gestión pública de tal manera requiere mucha clarificación (y extensión) de Las propias ideas de Simon cuando las presentó. La idealización resultante de la gestión pública como campo de estudio proporciona una base para un rico diálogo sobre la búsqueda de la excelencia académica en el estudio de las políticas públicas y la administración.

Palabras clave: administración pública, políticas públicas, ciencias sociales, investigación 


\section{The Study of Public Management: Conceptualizing a Design-Oriented Social Science}

In a visit to the mythical Pantheon for great minds in the study of public administration, a bust of Herbert $A$. Simon is encountered alongside a plaque praising his polymath proclivities, prodigious productivity, and profound impact. At the end of the tour, the Pantheon's bookshop is visited, some twenty minutes before closing time. Conspicuously displayed is a proud copy of Pantheon Greats. A quick flip through the pages turns up a chapter on Herbert A. Simon, as would be expected. Past the text's count of Simon's 500 publications, a summary of his early attack on traditional administrative theory is featured. The criticism that traditional administrative theory was theoretical without having a theory is striking. Impressed not only by Simon's publication output but also by Simon's rhetorical skill, the young public administration scholar leans back against the display table. An overview of the volume collecting Simon's prestige lectures at Berkeley and MIT, entitled Sciences of the Artificial, catches the eye. It's noted that in being published in 1996, the final edition falls safely within the Internet age.

The aim in perusing the Pantheon Greats entry on Simon shifts from gaining awareness of Sciences of the Artificial to seeking some measure of comprehension, even though the visitor is conscious of the shop's impending closure. Attention fixes on Simon's oft-quoted assertion that the goal of all professional practice is to convert existing into preferred conditions. The summary argument that neither philosophy of science nor the social sciences have enough to say about ontological and epistemological issues in the study of artificial phenomena rings true after pausing to consider it. The implication that "sciences of the artificial" should be adopted as a category of philosophical and interdisciplinary inquiry is consciously filed away.

Simon's asserted correspondence between professional schools and sciences of the artificial - the former being institutional homes for the latter - strikes the young scholar as straightforward, though he wonders if the point might be disputed by friends studying engineering at technological universities, or those studying management or public policy at stand-alone social science universities. He grins and winks in response to Simon's line that professional schools should do more for their students than transmit the results of fundamental research. The related principle that all practitioners should know how to participate in problem-solving no less when solutions for problems space straddle professional practice domains sounds perfectly well-adjusted to the age. The more specific line, that professional practitioners should be taught how to design, including how to represent knowledge, generate solutions, test generated solutions, evaluate tested solutions, and decide 
whether to adopt them, makes the young scholar want to see how Simon's argument plays out. With the dimming of lights signaling the bookshop's closure, however, Pantheon Greats is returned to its proud position on the display table.

Thanks to the well-known artificial phenomenon of Amazon.com, purchasing a personal copy of the Sciences of the Artificial is only a few quickclicks away. The book itself invites immediate attention once in hand. True to Simon's entry in Pantheon Greats, each compact chapter proves a stimulating read. The young scholar comes to understanding why Sciences of the Artificial became a notable reference in disparate fields of study and an icon for an earlier generation of academics with an interest in the study of management, the study of pubic administration, or both. For social scientists, early chapters recapitulate Simon's signature - and Nobelprize winning - conception of decision-making as a procedurally rational process in which (collections of) individuals decide that the status quo is not satisfactory, set out to search for information, convert some of the information that turns up into alternatives, and evaluate alternatives once formed - continuing this patterned process until a point where they have a satisfactory alternative in hand. At this point, the satisfactory alternative becomes "the decision" about what to do in response to the unsatisfactory status quo. For organization theorists, the volume makes available Simon's famed 1962 essay, "Architecture of Complexity," presenting a functional analysis of hierarchical forms of human organization. The chapter entitled, "The Science of Design - Creating the Artificial" was by all accounts seminal for the interdisciplinary field of design studies. Finally, the volume appealed to academic philosophers wishing for a fresh examination of ancient and modern views of how intentions and knowledge are converted into human-made patterns and arrangements known generically as "artifacts" (ARIEW, 2002).

For the Pantheon-going scholar, contemplating Simon's book produces heaps of questions, particularly about the broad domain of study that is helpfully termed "governmental and public action" in some academic and professional communities, notably in France (BARTOLI; BLATRIX, 2015). These questions deserve to be taken seriously, for the same reasons that Simon's book should be closely read and critically examined - not just admired, celebrated, and exploited as a symbol.

If a single heap in this domain represents a field of study like public policy or management, we can suppose that the questions stimulated by a thoughtful reading of Simon's book would exhibit similar forms; one might even suppose that the answers would fit a recognizable pattern, as well. Among the questions so stimulated might well be: Would it be appropriate and fruitful to conceive of fields of study as sciences of the artificial in exactly or nearly the way Simon presented the overall type, when they fall within the domain of governmental and public 
action? (An alternative would be to conceive such fields of study as sciences of institutional-behavioral phenomena, tout court; another alternative would be to see them entirely as prescriptive theories of professional practice, as in so-called traditional administrative theory.) What would be the significance for the values, priorities, and accomplishments of such fields of study if academics conceived of professional practice as responding to problems that - from the actor perspective - are not particularly tame, with the process of giving shape and detail to any such responses being conceived and presented as "designing" (HESKETT, 2002; LAWSON, 2004)? (An alternative is to conceive of professional practice as making decisions through deliberation about the situation and the strength of arguments about the dilemmas faced) ${ }^{2}$. Given a commitment to the idea that professional practice is designing, what sorts of design constraints or other implications would academics face as they carry out research and curriculum development?

This paper examines the relevance of Sciences of the Artificial to important and unresolved issues about how to make intellectual and scientific progress in fields of study - within the domain of governmental and public action - when they are conceived as "sites" not only for pursuing scientific understanding of institutionalbehavioral phenomena through research, but also for educating would-be professional practitioners.

This task is undoubtedly too big for a single paper, due to space constraints, and is just as certainly too broad for a single academic author, due to specialization. For these reasons, this paper treats these issues by way of an essay on one heap: the study of public management. Singling out this field of study for special attention is surely arbitrary in the larger scheme of things, but it is not without reason, in the circumstances: not only has public management been one of my main fields of study for a span of time equivalent to that of a generation, but considering these issues provides an avenue for addressing a nagging problem-mess in this field. The situation includes difficulties in pinning down its subject matter, particularly in concept (LYNN, 1996; HOOD, 2005). No less slippery is the issue of what kind of field of study this is. Neither condition is particularly propitious for making intellectual and scientific progress within this field, a factor that would in principle be unhelpful for research and education about the domain of governmental and public action, more broadly. ${ }^{3}$

\footnotetext{
${ }^{2}$ See Moore (1995) and Jonson and Toulmin (1988).

3 This paper's own direct precedents are Barzelay and Thompson (2010), Barzelay and Estrin (2012), and Barzelay (2012). Among the direct influences of those works are, beyond Simon (1996), van Aken (2004), Bardach (1993, 2004), Pawson and Tilley (1997), and Tilly (2006).
} 


\section{Characterizing Concepts}

The concept of design-oriented social science, which is newly presented here, draws conceptual structure from the established concept of sciences of the artificial. As the latter concept is highly elaborated, it will be helpful to subject it to analysis. The analytical approach used here is based on contemporary theorizing about human understanding, a key line of which is known as frame-semantics (FILLMORE, 1982; LAKOFF, JOHNSON, 1980; LAKOFF, JOHNSON, 1999; MURPHY, 2002; FAUCONNIER, TURNER, 2002). Within frame-semantics, a fundamental proposition is that the concepts that provide our cognitive understanding are composed of other concepts placed within an organized pattern of relationships.

When the mention of the term "universities" directs your cognition to the concept of universities, numerous concepts would come to mind, adding up to a collection such as professors, students, administrators, teaching facilities, campus grounds, sports arenas, schools, departments, taking out student loans, reputation for selectivity, conducting research, being promoted to tenure, reading in the library, taking exams, graduating, alumni, and endowing a chair. The collection of concepts to which cognition is directed wouldn't provide much in the way of understanding: however, knowing how such concepts fit into a relational pattern would provide a fuller sense of understanding. One relational pattern is the organization of concepts into differing subdomains, along the following lines:

Universities

Students

Professors

Alumni

Universities

Professors

Conducting research

Being promoted to tenure

Universities

Students studying

Taking out student loans

Reading in the library

Taking exams

Graduating 
Universities

Teaching facilities

Campus grounds

Sports arenas

An even fuller sense of understanding would come from knowing how to characterize relations among concepts that relate to semantic frames - not just categorization. Whey are organized into semantic frames, relations among concepts can be expressed in illustrative terms, such as:

Universities are where professors conduct research, where students study, and where professors teach students.

To analyze a concept in frame-semantic terms, then, requires us to identify the domains with which it is related as well as to characterize the relations among the concepts that are so identified, in accord with their roles in the wider concept as framed.

Identifying domains and categories, on the one hand, and characterizing conceptual relationships, on the other, can be quite a task. It is difficult to do so when conceptual relations are culturally entrenched, because it's inherently challenging to problematize that which is taken for granted. But it is also effortful when the target is a neologism like sciences of the artificial; in case like that, the challenge is to work out - and communicate with others - how the new conceptual entity is meant to relate to how we have previously come to understand the domains to which it relates.

The practical challenges of analysis and communication can be eased somewhat by employing means of visual representation. It is important that a format for visual representation be consistent with the selected theoretical ideas about cognition, language, and communication. In respect to frame semantics, two clear precedents are Lakoff and Johnson's (1980) Metaphors We Live By and Fauconnier and Turner's The Way We Think: Conceptual Blending and the Mind's Hidden Complexities (2002). These precedents will be followed in this section.

\section{Characterizing Sciences of the Artificial}

The label, "sciences of the artificial" suggests that it is a category of fields of study, specifically those that are scientific. All fields of study are characterized, in part, by their subject matter. Constrained by the semantic frame of fields of study, Simon had to find a way to characterize the subject matter of the collection of 
fields that count as sciences of the artificial. He opted for the standard - indeed, ancient - idea that a field of study's subject matter is some range of phenomena, conceived as types. The term he devised to play the role of type of phenomenon for the collection he labeled as sciences of the artificial was, "artificial phenomena." Whereas sciences of the artificial are concerned with man-made phenomena, the natural sciences are concerned with naturally occurring phenomena. The semanticframe that Simon developed in relation to fields of study and their subject matter can be formalized as:

Sciences of the artificial are fields of study whose specific subject matter falls within the category of artificial phenomena.

Simon further elaborated the concept of sciences of the artificial in relation to artificial phenomena, in four key ways. First, artificial phenomena come into existence through purposive human activity. Second, the result of such activity is an entity referred to as an artifact. Third, artifacts - once they exist - are capable of serving as a resource or tool for further purposive human activity. Fourth, the behavior of artifacts - and, hence, their usefulness - results from relational properties of the artifact and its environment. The concept of sciences of the artificial was also characterized in relation to universities. In his discussion of universities, Simon highlighted professional schools. Typical cases of professional schools include medical schools, engineering schools, schools teaching architecture, law schools, business schools, schools of public health, and public affairs schools.

The discussion so far can be summarized by listing - and then relating - key concepts within the "sciences of the artificial" domain:

Fields of study

Artificial phenomena

Sciences of the artificial

Professional schools

Education

Professional practice

Relations among the concepts in this semantic-frame can be characterized along the following lines:

Professional schools are institutions where students come for education in professional practice as well as in the sciences relevant to the kinds of artificial phenomena they will make and use in their work. 
A major direction in which Simon elaborated the frame of "sciences of the artificial" was to characterize the concept of "education for professional practice". It is here that "design" comes into the picture - or, less colloquially, comes to characterize the concept. In technical terms, the concept of "education for professional practice" becomes characterized by relations among the concepts of, naturally, professional practice, problem-solving, existing conditions, preferred conditions, artifacts, function, design activity, specification, testing, alternatives, evaluation, decisions, and use. Presented visually as a list, the concepts within this domain include:

Professional practice

Problem-solving

Existing conditions

Preferred conditions

Artifacts

Function

Design activity

Specification

Testing

Alternatives

Evaluation

Decisions

Use

Relations among the concepts in this domain can be characterized in the form of the several following statements:

Professional practice is essentially problem-solving.

Problem-solving is a process through which existing conditions are converted into preferred conditions.

Using artifacts is often conducive to problem-solving.

Problem-solving often results from bringing new artifacts into existence and putting them to use.

Designing contributes to bringing new artifacts into existence by (a) generating specifications, (b) testing whether artifacts made to such specifications would behave appropriately to their proper function with acceptable cost 
and acceptable undesired side-effects, under conditions in which the artifact might actually operate, and (c) providing specified and tested alternatives for evaluation and decision.

Education for professional practice includes learning how to participate in designing, i.e., generating artifact specifications and testing artifacts as specified, as well as learning how to evaluate alternatives that would be chosen for the sake of converting existing conditions into preferred conditions.

\section{Characterizing Public Management: Preliminary Remarks}

Within the professional school milieu of public policy, public affairs, and public administration, the term "public management" is broadly in use. The label is attached to individual courses, clusters of courses, and even degrees. In some professional schools, the term is wrapped into the official designation of faculty groupings. As a label, public management is also in use by meta-organizations that put on research conferences, edit scholarly journals, and claim to be communities of interest in public management as a field of inquiry, education, and outreach.

The visibility of the public management banner in professional school and meta-organization milieu, however, does not imply that the term carries the same meaning in one setting or discussion as in another. Indeed, close observation suggests that the term's meaning is familiarly ambiguous. A source of ambiguity is that "public management" is sometimes presented as being semantically identical to "public administration", while perhaps no less regularly being presented as categorically distinct. The source of this ambiguity has fortunately been illuminated by a number of observant academic authors (E.G.; LYNN, 1996) in recounting and commenting on the history of the scholarly labeling in the broad domain, whatever is its appropriate name.

Ambiguity in meaning can be cleared up fairly readily on a given occasion, if one is on guard, but the same is not true of vagueness. Ambiguity is present when the same term carries different but still well-established meanings; vagueness is present when characterizing the concept(s) to which a term would seem to refers takes inordinate cognitive and communicative effort. Of course, vagueness is not as bad as its reputation suggests: contemporary philosophy has praised natural language for being inherently vague as opposed to exact (VAN VAN DEEMTER, 2010). Whatever the merits of the general point, the difficulty in characterizing the concept(s) of public management is a matter for concern.

For immediate purposes, "public administration" refers to a complex - even contested - concept whose meaning is clear insofar as its characterization does 
not demand inordinate cognitive and communicative effort. It follows from this assertion that the meaning of "public management" is clear when the term refers to public administration. However, "public management" is vague when it does not. Note that saying that "public management" does not refer to public administration does not take a view as to how public management and public administration are conceptually similar and dissimilar. ${ }^{4}$

The concern here is the inordinate cognitive and communicative effort that is required to characterize the public management when the term is not being used to refer to public administration. This concern provides an occasion for attempting to convert existing conditions into preferred conditions, as Simon pithily characterized problem-solving. The intended conversion is from "public management" being a term for a vague concept to "public management" being a term for at least one clear concept. A step towards public management becoming a clear concept is to provide a worked example of the application of a methodical means to achieve clarity; a complementary step is to characterize public management in a way that is appropriate to occasions like the present one, where the shared goal is to remove obstacles to intellectual progress.

A feature of the method to be used here has something in common with both fiction and innovation: the willing suspension of disbelief (HOOD; JACKSON, 1991). In particular, the method cannot work if the reader does not "assume away" some existing conditions that make it difficult to convert vagueness into clarity. Conditions to be assumed away include the current configuration and operation of the "guessing machines" that give rise to cognitive and communicative responses to receipt of "messages" from others (HEATH; HEATH, 2008). The current guessing machine configuration is not known with certainty, but there is reason to believe that it includes "folk theories" of conceptualization rather than ones that have been developed in cognitive science, such as elaborations on the theory of framesemantics (LAKOFF, 1987). There is also reason to suppose that guessing machines will be anchored in what has been seen as the key practical imperative: to make "public management" meaningful as a term directed at professional practitioners rather than to academics keen to be part of intellectual and scientific progress. More could be said about the need to monitor guessing machines and to suspend disbelief; let us proceed nevertheless.

\footnotetext{
${ }^{4}$ Personally, I have a pro-attitude toward seeing the conceptual similarity in terms of category inclusion, where "public administration" is the inclusive category-term. The vital relation between the concepts is thus seen, as an abstract and general matter, as that of part-whole" (Fauconnier and Turner 2002). I place this remark in a footnote to signal that this paper is not deeply concerned with how the terms "public administration" and "public management" should be used in relation to one another. Much ink and pixels have been devoted to this linguisticinstitutional issue.
} 
The exercise on which we are about to embark is to characterize public management, the concept. For the avoidance of doubt, the nature of the exercise is to attribute conceptual structure to public management, as opposed to discovering what conceptual structure has come to be entrenched through cultural transmission. Performing the task of attribution requires conducting the activity of specification. Specification, to pose a dichotomous choice, can be carried out in a formulaic or design-oriented way. For the challenge at hand, a design-oriented problem-solving style is more appropriate than a formulaic one. The rationale for this assertion is two fold. First, a vaguely conceptualized field of study is inherently an "ill-structured" though surely not wicked - problem- solving challenge. Second, design-oriented problem-solving styles are appropriate to ill-structured problem-solving challenges.

A characteristic of a design-oriented problem-solving style is to search for relevant information that can be sorted into the broad baskets of design precedents, design references, and background knowledge. First, the concept of design precedent is characterized by the concept of already existing artifacts or other creations as well by the concepts of description and commentary. A design precedent is something that would be reverse engineered or play some other role in design activity. Second, the concept of design reference is characterized by the concept of formal knowledge. Much codified knowledge that serves as design references is functional-teleological argumentation about kinds of challenges and their problems and solutions, though some codified knowledge is generalizing argumentation about scientifically studied subjects or a combination of the two. Some design references are concerned with design activity, while others relate to sort of item being designed. Third, the concept of background knowledge is characterized as relevant information that would nevertheless be out of place in the design precedent and reference baskets. Much background knowledge is spatio-temporally local rather than distal.

The "design precedents" selected for the design task reported in this paper include Simon's Sciences of the Artificial. They also include a number of publications calling for the study of management to be modeled on the idea of sciences of the artificial, several of which are authored by Joan van Aken. The selected design precedents include extended treatments of the very question of what the study of public management is, with Lynn (1996) standing out as one worthy of close study. And the design precedents include passages about what the study of public management is that have been weaved into conspicuous publications in the field (MASHAW, 1983; MOORE, 1995; BARDACH, 2004; BRYSON, 2011). In turn, the "design references" selected for converting the vague concept of public management into a clearer one, suitable for eliminating obstacles to intellectual and scientific progress, include literature on conceptualization and conceptual change; design activity; governmental and public action; and, of course, management. 


\section{Characterizing the Study of Public Management: One Step at a Time}

Characterizing public management is necessarily a step-by-step process. The first step is to acknowledge that the goal of removing obstacles to intellectual and scientific progress carries implications for the conceptual structure of public management. The implication is that public management is characterized as a vital field of study. This reason for the implication comes from background knowledge about intellectual and scientific progress, which is that it is hard to make such progress in relation to a subject matter in the absence of research and educational activities that fall under the overall description of a field of study exhibiting vitality. None the subsequent steps in characterizing public management will backtrack from this specification, namely that "public management is a vital field of study."

The second step is to acknowledge that the commitment to public management being characterized as a vital field of study carries implications. Background knowledge suggests that vital fields of study exhibit conceptual clarity about their subject matter. Conceptual clarity does not equate to having a monolithic view. For example, the discipline of economics is quite divided as to whether its subject matter is economic life or its subject matter is that which proves amenable to certain forms of theoretical or scientific treatment; nevertheless, the discipline of economics exhibits vitality as well as conceptual clarity in respect to each contending account of the subject matter of the field. Acknowledging this piece of background knowledge implies that if public management is to be conceived as a vital field of study, we need to characterize its subject matter. Let us tackle this issue before considering directions of specification for the loosely coupled activities in any field of study: research and education.

Characterizing the subject-matter aspect of public management as a field of study, is an ill-structured problem in itself - even if the goal of making intellectual and scientific progress is adopted, and even if it is agreed that being a vital field of study is necessary to achieving this goal. To make headway, let us plumb background knowledge to identify some considerations that constrain conceptual choices about the field of public management's subject matter. Background knowledge suggests that public management should be concerned with - in no particular order - management and governmental/public action. Characterizing the implications of this background knowledge requires some careful discussion. First of all, what we mean by "management" and "governmental/public action" is inherently constrained by the goal of making intellectual and scientific progress in the study of public management. To make such progress, it would be advantageous to constrain "management" to the study of management. The rationale comes from background knowledge about intellectual and scientific progress: the potential 
benefits of interdisciplinarity are likely to be realized only if existing field of study become connected. As the same rationale applies to "governmental/public action", the constraint is that the study of governmental/public action should be reflected in the study of public management.

Now, the expression "should be reflected in" needs a measure of characterization. At this point in our discussion, the only issue is how to characterize the subjectmatter of the study of public management in conceptual terms. To pinpoint the step that needs to be taken here, it is helpful to consider the study of conceptualization as a design reference. Within that field of study, a theoretical generalization is that connections between a given pair of conceptual domains can take the form of conceptual similarities.5 Given the present discussion's goal, the implication is that the subject matter of the study of public management should be conceptually similar to the subject matter of (a) the study of management and (b) the study of governmental/public action. In what follows, I take this implication as a design constraint on how the subject matter of the study of public management is characterized - at the risk of repetition, for the sake of eliminating obstacles to intellectual and scientific progress.

This design constraint is specific in saying that certain relations among concepts have to hold, but it is otherwise unspecific. It becomes more specific insofar as content is given to "the subject matter of the study of management" and to "the subject matter of the study of governmental/public action." In the interest of managing attention, let me flash-forward to the beliefs that I have formulated and the conclusions I have reached about these issues.

Expressed as a single concept, the subject matter of the study of management in frame-semantic terms - is ventures. The role of venture is to refer to the concept of that which is managed, conceived comprehensively. ${ }^{6}$ This concept - that which is managed - is not best referred to as "organizations". The reason is that for more than 50 years, the term "organization" has been used by social scientists in characterizing what is universal about ventures as organizations. When ventures are characterized as organizations, patterns and arrangements in their social systems - such as formalized roles, intergroup interactions, resource dependencies, and collective decision-making - receive persistent attention; by contrast, however, patterns and arrangements in their purposive activities - such as conducting

\footnotetext{
${ }^{5}$ To use a standard example, there is typically a connection between the conceptual domain of goal-seeking action and the conceptual domain of journeys; the relation between (a) "existing conditions" and (b) "the goal sought" is conceptually similar to the relation between (a') a journey's "point of departure" and (b') a journey's "destination".

6 The terms "conceived in their totality" or "conceived holistically" could be used in place of "conceived comprehensively."
} 
combat operations or exchanging ownership of commodity futures contracts receive cursory attention. The result is an unbalanced understanding of ventures, an assessment that follows from seeing the study of management as being just as concerned with patterns and arrangements in ventures' purposive activities as with patterns and arrangements in ventures' social systems.

The view just taken is backed by precedents that can be found in a variety of precincts of the academic world. A clear precedent within the study of business management is Michael Porter's (1985) Competitive Advantage, with its fulsome discussion about managing a focal venture's businesses through modifying their value chain configurations, with a view to counteracting the competitive forces that tend to diminish the profitability of a venture's businesses. In the study of governmental and public action, a clear counterpart to Porter's theory of business management is the program evaluation literature, especially works concerned with formative (and, no less, developmental) evaluation. These precedents make the point indirectly, by favoring fine-grained attention to patterns and arrangements in purposive activity, in contrast to literature that conceptually centered on organizations. However, the same key point has also been made directly, in a balanced way. The source is the late distinguished political scientist, Charles W. Anderson, in a passage within his elegant synthesis of Pragmatism as a political theory of contemporary society:

A distinction should be made between the enterprise and the organization. The organization is more often the more tangible entity, easier to grasp and identify.... \{However], when thinking about social performance we will more likely focus on the enterprise. When discussing private government, we will also take the organization into account, for the corporation, the union, the university, the guild, and the church as pertinent and often problematic elements of political order (ANDERSON, 1990: 18-19).

In this passage, Anderson characterized ventures as enterprise-and organizationlike. This characterization is important to elaborating the concept of venture within the study of management, as well as within the study of public management. The subject matter of the study public management therefore should be conceptually similar to enterprise-and organization-like ventures.

To preserve the concept of venture, while giving it the specificity needed to hit the target of characterizing the subject matter of the study of public management, key issues to consider are what "values" (MARSHALL, 1995) to give to the two concepts of enterprise-like and organization-like, which are lexically instantiated as adjectives in the expression "enterprise- and organization-like ventures." Speaking to these issues in reverse order, my considered views are as follows. 
First, a candidate value for organization-like is public bureaucracies. No doubt, public bureaucracies are an abstract central case of the concept that plays the conceptual role of organization-like within the semantic frame that characterizes the subject matter of the study of public management. This is a good reason to consider it very strongly. However, background knowledge suggests that the concept of public bureaucracies is not the only candidate. In fact, the study of governmental and public action - having taken notice of such practices as contracting out and publicprivate partnerships - has clearly overridden the idea that public bureaucracies are the single abstract central case of organization-like aspects of ventures within that field. Given the earlier stated design constraint of maintaining consistency between the subject matter of the study of governmental and public action and the subject matter of the study of public management, there is no gain to be had in giving the concept of organization-like a more specific value when characterizing the latter.

Second, sufficient differentiation of public management can be achieved by giving a more specific value to the concept that plays the role of enterprise-like in what we can call "the study of management semantic frame." A candidate for this role is public program. Within the field of study of governmental and public action, the term "public program" undoubtedly refers to an abstract central case of the concept of enterprise. On the basis of experience I have not come across any other single abstract case of the concept of enterprise in the governmental and public action field of study. With my mind tethered to this impression, I consistently see the concept of public program as playing the role of enterprise when reading the public management literature, whether treatises (E.G., MOORE, 1995; BRYSON 2011) OR MONOGRAPHS (E.G., MASHAW, 1983; TENDleR, 1997; BARDACH, 1998; BARZELAY, CAMPBELL, 2003, DURANT, 2007). For all these reasons, I conclude that the subject matter of the study of public management is public program- and organizationlike ventures.

This characterization is compatible two variations on this statement. One is that the subject matter of the study of public management is types of public programand organization-like ventures. This variation is helpful as a reminder that research about public management is directed at knowledge about types of phenomena, whether artificial and/or social. The same variation also points to the fact that research about governmental and public action has long been directed to attaining knowledge about differentiated types of public program-and organization-like ventures, as is plainly illustrated by Lester Saloman's (2002) edited volume on tools of government and James Q. Wilson's (1989) research synthesis, Bureaucracy. The second variation is to state that the subject matter of the study of public management is life courses of public program- and organization-like ventures. This variation is 
due to the influence of Philip Selznick's monographic studies of governmental and public action as well as to the deep impression made on the study of management by his synthetic and more prescriptive book, Leadership in Administration (SELZNICK, 1957). These two variations can be combined to form the impossible-to-remember but precise statement that the study of public management's subject matter is types of public program and organization-like ventures, viewed within particular time windows and over their life course. At the risk of being elliptical, this thought can be condensed into the core and compact statement that, "the subject matter of the study of public management is life courses of public program- and organizationlike ventures."

As has become apparent, a feature of this paper's overall argument is that the study of public management should hew to the idea of being a design-oriented social science. We have now built-in the additional feature of characterizing the subject matter of the study of public management. This feature contributes to converting "public management" from a vague idea into a clear concept. While the subject matter of the study of public management is now clear, the idea that this field is a design-oriented social science remains vague. Our day's work is not yet complete.

\section{What Sort of Thing is the Study of Management?}

By construction, the concept of public management is conceptually related to the concept of sciences of the artificial. The abstract form of the relation is sourceto-target, where the role of source is played by sciences of the artificial. This sourceto-target relation is intimate: specifically and technically, the concept of sciences of the artificial is "projected into" the concept of public management. Source-totarget projections are special cases of source-to-target connections (FAUCONNIER, TURNER, 2002). This particular connection is reflected lexically in the title to this paper: "Public Management as Design-oriented Social Science."

To fine-tune one's comprehension of the source-target conceptual similarity, it is important to be clear about conceptual relations within the source, sciences of the artificial. Fine-tuning can be accomplished by tracing how Simon built structure this semantic-frame. The first step involved two almost indistinguishable moves. The first move was to characterize sciences of the artificial as an abstract case of fields of study. The second move was to project conceptual structure from fields of study into sciences of the artificial by preserving conceptual relations within fields of study that involve subject matter, research knowledge, education, and learning. The second step also involved three moves that constructed relations among these and other concepts within sciences of the artificial. The first of these moves was to 
assign the value of preparing for professional practice to the semantic-frame slot of learning, which had been projected from fields of study. The second of these moves was to elaborate the projected conceptual structure involving education and learning: specifically, to introduce a third conceptual value for education, alongside teaching and learning. Simon referred to this third value for the education slot as "curriculum development."

The third move was to present an argument along the following lines. Being taught the research knowledge of a science of the artificial (such as architecture or mechanical engineering) is insufficient in relation to seeking to become a professional practitioner in the corresponding professional practice field. So too, being educated about the research knowledge of the study of design is insufficient in relation to the goal of becoming a professional practitioner in the field of professional practice (such as office tower architecture or fluid power). Speaking more colloquially, to know your science but not design, or to know design, but not your science, is a poor educational outcome for a student of a science of the artificial. The same is true for knowing your science and knowing design, but not knowing design in relation to your research knowledge-based professional practice. To put this last point in both positive and less colloquial terms: the professional practitioner needs to be taught and learn curriculum that has integrated (a) research knowledge about the subject matter of their science of the artificial with (b) knowledge about converting existing-into-preferred-conditions for their field of professional practice. To close the circle of this argument, a challenging requirement for any science of the artificial is to develop curriculum that successfully integrates research knowledge about the subject matter of a particular science of the artificial with (what some call) design knowledge (DYM, 1994) that is not specific to any such field of study.

In sum, in Sciences of the Artificial, Simon in effect mixes in a positive attitude toward the study of management being a design-oriented, social science, even as the study of management did not count as a central case of sciences of the artificial as a more abstract type. However, the specifics of his position are not readily clear. We can take it that curriculum in management should relate to conceptions of problem-solving and design; we can know that Simon considered fundamental research knowledge about organization design to be important to curriculum in the study of management, for he stated that it was important to the curriculum of any science of the artificial. What is not clear, however, is what research knowledge about the subject of management, specifically, is needed to form part of an integrated curricular whole. For these reasons and others, my assessment is that Simon's writings can only be seen as a forerunner of the idea that the study of public management (or of management) is a design-oriented social science. 
Attempts have been made to pick up where Simon left off in terms of what might be called "meta" discussions of the study of administration and management. A foray in this direction was an article in Public Administration Review, entitled "Public Administration as a Design Science" (ShANGRAW, Crow, OVERMAN 1989). Joan van Aken has more recently made a series of contributions, including his highly cited article in Journal of Management Studies, entitled, "Management Research Based on the Paradigm of the Design Sciences" (2004) as well as a particular good discussion of this approach in the context of organizational development (VAN AKEN, 2007). Because van Aken - unlike Simon - has actually provided a substantial body of commentary on taking a design-oriented approach to the study of management, specifically, it is appropriate to consider his perspective, at least in brief. ${ }^{7}$

Van Aken adopted the term "design science" to present the design-oriented study of management. Should we be content with this presentational labeling? The issue arises because presenting the study of management as a "design science" is different from presenting it as a "science of the artificial", for the reason that the two terms refer to different concepts in Sciences of the Artificial.

Consider the case of architecture. Architecture is not a design science, but a science of the artificial. Students learn science, and they learn design. An architecture student will take scientific courses - about natural phenomena, like mechanical forces and soils, and institutional-social phenomena, like urban planning - as well as courses on architectural practice. The curriculum on architectural practice, in particular, involves applying the sciences relevant to architecture to problems of professional practice. Simon came up with the term "design science" to refer to what he hoped would come to serve as a theoretical and scientific basis for that part of an education program whose role is to prepare students for professional practice, in architecture as in other cases of sciences of the artificial. Just to be clear, students of architecture study architecture in preparation for professional practice. They do not study a design science, and they do not practice one. They study and practice a science of the artificial. That does not mean that no one is to study "design science." What Simon argues is that it's the professors who need to study "design science" in order to develop - and plead for the legitimacy of - practicum courses. We lose sight of all these points by repacking "science of the artificial" as "design science."

If we accept that Simon said little about the study of management as part of his "sciences of the artificial" argument, and if we treat van Aken as the most conspicuous, thoughtful, and forceful spokesperson for conceiving the study of management in a design-oriented way, then we cannot duck the question ofappropriate labeling. Should we adopt van Aken's term "design science" to label

${ }^{7}$ I have discussed van Aken's work in detail in Barzelay (2012). 
a design-oriented conception of the study of management? A few assumptions need to be made explicit in order to proceed to give a response. One assumption perhaps a brave one - is that Simon truly considered the study of management as a "normal" case of a science of the artificial, i.e., conceptually similar to other cases of the type, such as the study of architecture or the study of mechanical engineering. A second assumption is that van Aken holds to the same view. A third assumption is that van Aken intends to present his conception of the study of management as substantively similar to Simon's conception of the study of management as a science of the artificial. Given these assumptions, we should be inclined to reject van Aken's presentation of the study of management as a "design science" on the grounds that it sows confusion for reasons that should be clear by now. This inclination could be countered, however, by arguing that shifting terminology is justified for reasons of rhetoric or, more precisely, packaging. Design science is a plainly a catchier expression. If packaging considerations are to be given sufficient weight to be a conclusive reason to substitute the label "design science" for "science of the artificial," then so be it. But the argument has to be made, and the difficulties sowed by the shift ought to be acknowledged. (These difficulties include papering over the ambiguities, equivocations, and possible blindspots in Simon's conception of the study of management in relation to the concept of a science of the artificial.)

My own view is that "science of the artificial" is a very good concept for the study of management but a poor label for reasons of packaging. "Design science" is evidently a semiotic winner. If we had to choose between "science of the artificial" and "design science", then the latter would get my vote. However, this is a false binary choice. What we need is a term that references Simon's concept of a science of the artificial, but picks up on the "design" theme, with its cultural caché and role as a metaphor for professional practice. These label-design criteria are satisfied by the term, "design-oriented social science." While not as catchy as design science, the term does not create obstacles to dealing with the unfinished business that we face in making sense of the idea that "the study of management is a science of the artificial." Hence, the title of this paper and the book-length treatment in preparation: Public Management as Design-Oriented Social Science.

\section{Conclusion}

Looking back on the distance covered, we can appreciate the effort involved in removing ambiguity as to whether "the study of public management" refers to "the study of public administration" or rather, like "the study of public administration" itself, to an aspect of the "study of governmental and public action." We can appreciate the effort to add clarity to the subject matter of the study of public 
management by solving a conceptual design problem that included the design constraints of preserving conceptual similarity with both the study of management and the study of governmental and public action. We can be content with the result of this effort, namely the compact but somewhat elliptical statement that the subject matter of the study of public management is life courses of public programand organization-like ventures. We understand that to say that the study of public management is a design-oriented social science is to say that the study of public management is a "case" of a science of the artificial.

Looking ahead, we know that this status means that when further detailing the concept of the study of public management, we have to respond to (cognitive and dramaturgical) pressure to preserve the lines of Simon's argumentative discussion (and the underlying conceptual relations) involving education, research knowledge, professional practice, problem solving, and design. The prospect of handling this pressure does not feel terrifically daunting as the cultural systems of the study of management and the study of governmental and public action support a proattitude toward arguments along the lines that education for professional practice involves learning how to convert existing into preferred conditions.

While this paper is concerned with a "case" within the study of governmental and public action, it is presented as a parable for other lines of work in research and education within this broad and fuzzy-edged domain, particularly where the term "design" is a feature of conceptual thinking, habits of thought, and/or packaging. The point of my parable is that we may well have a challenge in putting the study of governmental and public action on the right intellectual footing. The "case" of the study of public management shows that it's possible for a field of study in the realm of governmental and public action to be vague about its subject matter and to equivocate about whether it is a science of institutional-behavioral phenomena or a science of the artificial.

This paper has illustrated the utilization of intellectual resources for the purposes of converting conceptual vagueness into conceptual clarity. In doing so, it has illustrated how we can covert an ill-structured problem mess into a fairly structured problem. In responding to this situation, we might well take the time to examine matters of conceptualization. Continued progress in designing a solution to these conceptual matters will, I believe, be of enormous help in eliminating obstacles to intellectual and scientific progress, in the study of pubic management. Replicating this approach for other "cases" in the study of governmental and public action may be called for, depending on assessment of the challenges we collectively face. 


\section{References}

Anderson, Charles W. Pragmatic liberalism. Chicago: University of Chicago Press, 1990.

ARIEW, André. Platonic and aristotelian roots of teleological arguments. In: ARIEW, André; Cummins, Robert; PerLman, Mark (Eds.). Functions: new essays in the philosophy of Psychology and Biology. Oxford: Oxford University Press, 2002.

BARDACH, Eugene. Getting agencies to work together: the practice and theory of managerial craftsmanship. Washington, D.C.: Brookings Institution Press, 1998.

Comment: the problem of 'best practice' research. Journal of Public Policy Analysis and Management, v. 13, n. 2, p. 260-268, 1993.

Presidential address - the extrapolation problem: how can we learn from the experience of others? Journal of Public Policy Analysis and Management, v. 23, n. 2, p. 205-220, 2004.

BARTOLI, Annie; BlatriX, Cécile. Management dans les organisations publiques: défis et logiques d'action. Paris: Dunod, 2015.

BARZELAY, Michael. The study of public management: reference points for a design science approach. In: TRIA, Giovanni; VALOTTI, Giovanni (Eds.). Reforming the public sector: how to achieve better transparency, service and leadership. Washington, D.C.: Brookings Institution Press, 2012.

Barzelay, Michael; CAMPBelL, Colin. Preparing for the future: strategic planning in the U.S. Air Force. Washington, D.C.: Brookings Institution Press, 2003.

BARZELAY, Michael; THOMPSON, Fred. Back to the future: making public administration a design science. Public Administration Review, v. 70, n. 1, p. 295-297, 2010.

BARZELAY, Michael; ESTRIN, Saul. Design science as a reference point for management research. In: MoRsing, Mette; SAUQUET, Alfons (Eds.). Business schools: which contribution to society? London: Sage, 2012.

BRYSON, John M. Strategic planning for public and nonprofit organizations: a guide to strengthening and sustaining organizational achievement. 4. ed. New York: John Wiley, 2011.

DURANT, Robert F. The greening of the U.S. Military: environmental policy, national security, and organizational change. Washington, D.C.: Georgetown

University Press, 2007.

DYM, Clive L. Engineering design: a synthesis of views. Cambridge: Cambridge University Press, 1994.

FAuconnier, Gilles; TURNer, Mark. The way we think: conceptual blending and the mind's hidden complexities. New York: Basic Books, 2002.

FILLMORE, Charles. Frame semantics. In: LINGUISTIC SOCIETY OF KOREA (Ed.). Linguistics in the morning calm. Seoul: Hanshin, 1982.

Heath, Chip; HeAth, Dan. Made to stick: why some ideas take hold and others come unstuck. London: Random House/Arrow Books, 2008. 
HESKETT, John. Design: a very short introduction. Oxford: Oxford University Press, 2002.

Hood, Christopher. Public management: the word, the movement, the science. In: FerLIE, Ewan; LYNN, Laurence; PolLITT, Christopher (Eds.). The Oxford Handbook of Public Management. Oxford: Oxford University Press, 2005. p. 7-26.

HOOD, Christopher; JACKSON, Michael. Administrative argument. Aldershot: Dartmouth, 1991.

JONSEN, Albert R.; TOULMIN, Stephen. The abuse of casuistry: a history of moral reasoning. Berkeley: University of California Press, 1988.

LAKOFF, George. Women, fire, and dangerous things: what categories reveal about the mind. Chicago: University of Chicago Press, 1987.

LAKOFF, George; JOHnSON, Mark. Metaphors we live by. Chicago: University of Chicago Press, 1980.

Philosophy in the flesh. New York: Basic Books, 1999.

LAWSON, Bryan. What designers know. Oxford: Architectural Press, 2004.

LYNN JR., Lawrence E. Public management as art, science, and profession.

Chatham, NJ: Chatham House, 1996.

MARSHALL, Sandra P. Schemas in problem solving. Cambridge: Cambridge University Press, 1995.

MASHAW, Jerry L. Bureaucratic justice: managing social security disability claims. New Haven, CT: Yale University Press, 1983.

MoORE, Mark H. Creating public value: strategic management in government. Cambridge, MA: Harvard University Press, 1995.

MURPHY, Gregory L. The big book of concepts. Cambridge, MA: MIT Press, 2002.

PORTER, Michael E. Competitive advantage: creating and sustaining superior performance. New York: Free Press, 1985.

SALAMON, Lester (Ed.). The tools of government: a guide to the new governance. Oxford: Oxford University Press, 2002.

SELZNICK, Philip. Leadership in administration: a sociological interpretation. New York: Row, Peterson and Company, 1957.

SIMON, Herbert A. Sciences of the artificial. 3. ed. Cambridge, MA: MIT Press, 1996.

ShangraW Jr., Ralph F.; Crow, Michael M.; OVERMAN, E. Sam. Public administration as a design science. Public Administration Review, v. 49, n. 2, p. 153-160, 1989.

TENDLER, Judith. Good government in the tropics. Baltimore: Johns Hopkins University Press, 1997.

TILly, Charles. Why? What happens when people give reasons, and why?

Princeton: Princeton University Press, 2006.

VAN AKEN, Joan E. Management research based on the paradigm of the design sciences: the quest for field-tested and grounded technological rules. Journal of Management Studies, v. 41, n. 2, p. 219-246, 2004. 
Design science and organizational development interventions: aligning business and humanistic values. Journal of Applied Behavioral Science, v. 43, p. 67-88, 2007.

VAn DeEMTER, Kees. Not exactly: in praise of vagueness. Oxford: Oxford University Press, 2010.

WILSON, James Q. Bureaucracy: what government agencies do and why they do it. New York: Basic Books, 1989.

Michael Barzelay

É Professor de Public Management no Department of Management da London School of Economics and Political Science (Reino Unido). Contato: m.barzelay@lse.ac.uk 